\title{
KETERKAITAN DESA-KOTA: SEBAGAI ALTERNATIF PEMBANGUNAN PERDESAAN
}

\author{
Oleh: \\ Suparmini \\ Jurusan Pendidikan Geografi, FISE UNY
}

\section{Abstrak}

Masalah yang dihadapi masyarakat perdesaan adalah rendahnya kualitas hidup, tingginya pengangguran serta sistem produksi dan diversivikasi yang belum berkembang. Akibatnya terjadi kesenjangan kesejahteraan masyarakat perdesaan dibanding dengan masyarakat kota.Oleh karena itu perlu adanya upaya dan pemikiran untuk memperkecil kesenjangan tersebut.

Program Pembangunan dengan mengutamakan keterkaitan desakota, program pembangunan ini didasarkan pada teori pembangunan pusat-iepi (core periphery) dari Friedman, teori polarisasi ekonomi dari Hirschman, serta teori ekonomi dari Myrdal. Ketiganya sepakat bahwa hubungan pusat-tepi dapat menumbuhkan pertumbuhan ekonomi wilayah. Untuk memperbesar spread effects dan memperkecil pengaruh backwash effects, Myrdal memandang perlu adanya intervensi pemerintah. Sedangkan Hirschman yakin bahwa perbedaan ekonomi keruangan desakota bersifat sementara saja, karena dengan pembangunan yang merupakan intervensi peinerintah akan mempercepat menghilangkan ketimpangan keruangan tersebut. Keberhasilan pendekatan pembangunan perdesaan yang merupakan proses peningkatan kemampuan masyarakat dan penguatan keterkaitan desa-kota tergantung pada keterlibatan pemerintah, masyarakat sendiri, swasta serta lembaga masyarakat.

Kata kunci: desa, kota, pembangunan perdesaan

\section{Pendahuluan}

Dewasa ini sekitar 70 persen penduduk Indonesia bertempat tinggal di perdesaan. Oleh karena itu agar pembangunan dapat berhasil dengan baik dan sekaligus dapat meningkatkan penghidupan masyarakat 
perdesaan, maka partisipasi masyarakat perdesaan dalam pembangunan sangat diperlukan.

Untuk itu berbagai upaya pembangunan telah dilakukan oleh pemerintah untuk membangun perdesaan. Hal tersebut dimaksudkan untuk (1) mengembangkan warga perdesaan agar setara dengan warga kota; (2) meningkatkan penghidupan warga perdesaan; (3) agar warga perdesaan lebih kreatif, dinamis dan fleksibel dalam menghadapi berbagai kesulitan sehingga dapat meningkatkan semangat pembangunan. Sudah selayaknya intervensi pemerintah dalam mengembangkan masyarakat perdesaan akan menghasilkan dampak yang setara dilihat dari ukuran kesejahteraan, mengingat bahwa setiap warga negara dalam suatu negara mendapat hak kesejahteraan yang adil melalui peranan pemerintah.

Permasalahannya adalah bahwa walaupun telah banyak intervensi oleh pemerintah untuk pengembangan perdesaan, ternyata masih terdapat jurang kesenjangan (gap) tingkat kesejahteraan masyarakat perdesaan dan perkotaan. Oleh karena itu perlu adanya pemikiran untuk mengembangkan kebijaksanaan, agar kesejahteraan masyarakat perdesaan setara dengan masyarakat perkotaan.

\section{Ciri-Ciri Daerah Perdesaan dan Perkotaan}

Secara umum daerah perdesaan ditandai oleh struktur kegiatan penduduk berbasis agraris atau pertanian, kepadatan penduduk lebih rendah dibanding kepadatan penduduk perkotaan, cara hidup ataupun pola budaya yang dekat dengan pemanfaatan sumber daya alam, tempat tinggal penduduk berkelompok dan tersebar, potensi tenaga kerja dengan pendidikan baik agak langka, sistem organisasi sederhana berbasis kegiatan subsisten atau primer, dan sebagainya.

Sebaliknya ciri masyarakat perkotaan ditandai oleh struktur masyarakat berbasis perdagangan dan jasa, kepadatan penduduk rapat, tempat tinggal penduduk berkelompok, tenaga berpendidikan relatif tinggi, sistem organisasi kerja yang kompleks berbasis kegiatan formal. Kawasan perkotaan juga dianggap sebagai tempat terjadinya proses pemusatan kekuasaan dan perubahan budaya, pusat kreativitas yang menyebabkan terjadinya pola perkembangan kehidupan masyarakat dan lingkungan fisiknya sangat berbeda dengan kawasan perdesaan yang biasa disebut pinggiran.

Banyak ahli yakin, walaupun ciri dan kegiatan kedua masyarakat itu berbeda, tidak berarti bahwa tingkat kesejahteraan harus berbeda. Terlebih lagi seharusnya tidak ada perbedaan perlakuan dalam memberikan 
pelayanan antara masyarakat perdesaan dan perkotaan, misalnya terhadap standar pelayanan kebutuhan dasar, standar pelayanan prasarana, standar pelayanan teknologi dasar. Kesimpulan sementara ini terhadap terjadinya kesenjangan secara umum disebabkan oleh ketidakseimbangan kemampuan dan kesempatan yang diperolah antara masyarakat perdesaan dan perkotaan.

Terdapat dugaan bahwa masyarakat perdesaan di Indonesia mempunyai posisi yang kurang diuntungkan dari adanya berbagai kebijaksanaan pemerintah, yang kurang memihak, yang menyebabkan proses produksi dan kapitalisasi tidak berkembang secepat yang terjadi di perkotaan. Disamping itu di perdesaan juga sering terjadi migrasi sumberdaya manusia ke daerah lain yang lebih maju. Akibatnya secara keseluruhan respons terhadap proses pembangunan tidak optimal, walaupun input kesempatan yang diberikan kepada masyarakat mungkin sama dengan kesempatan yang diberikan terhadap masyarakat di daerah perkotaan.

Kecenderungan ini dapat diubah jika alokasi sumberdaya pembangunan dan proses manajemennya dapat diarahkan secara seimbang kepada masyarakat perdesaan agar tingkat kesenjangan kesejahteraan masyarakat perdesaan dan perkotaan berkurang. Salah satu hipotesis yang diajukan adalah jika produksi dan produktivitas di perdesaan lebih berkembang, akan terjadi diversifikasi yang selanjutnya akan diikuti dengan peningkatan pendapatan dan tabungan di masyarakat, sshingga terjadi akumulasi modal dan peningkatan teknologi di masyarakat.

Salah satu faktor utama yang dapat menyebabkan timbulnya percepatan peningkatan produksi dan produktivitas yang mendorong perluasan kesempatan kerja, peningkatan pendapatan dan tabungan, serta kapitalisasi di masyarakat perdesaan adalah jika terjadi keterkaitan ekonomi yang erat dengan arus perdagangan dengan pihak luar (Hiroshi Kakazu, 1994: 10 - 16).

$\mathrm{Hal}$ ini dapat diartikan bahwa peningkatan dan perubahan struktur ekonomi perdesaan dapat terjadi bila terdapat kemampuan masyarakat untuk menjual produk dan jasa ke pasaran luar kawasan, terjadi transaksi ekonomi antar produsen dan pembeli, antar sektor usaha, antar daerah, bahkan dengan negara lain (Evans H.E: 1994). Proses rekayasa keterkaitan inilah yang dictuga sebagai landasan upaya meningkatkan dan mengubah kehidupan masyarakat perdesaan menjadi lebih berkembang, karena kegiatan produksi dapat memperbesar pendapatan masyarakat, mengubah 
pola pendapatan dan pengeluaran keluarga yang makin setara dengan masyarakat kota, atau dikatakan sebagai kehidupan yang modern.

Pemahaman tersebut didasarkan pada pemikiran dasar bahwa pada dasarnya masyarakat perdesaan pun bersifat dinamis untuk dapat mengalami proses modernisasi, jika terjadi perubahan struktur ekonomi sosial. Modernisasi merupakan wujud nyata proses urbanisasi, dimana urbanisasi merupakan proses yang digerakkan oleh perubahan struktural dalam masyarakat, sehingga daerah yang dulunya merupakan perdesaan lambat laun menjadi perkotaan atau masyarakat berubah mempunyai ciri seperti kehidupan kota (P.J.M. Nas, 1979: 42).

Pengertian tersebut dapat memunculkan pertanyaan-pertanyaan (a) apakah perubahan struktural masyarakat perdesaan menjadi bercirilian seperti masyarakat perkotaan dapat berlangsung di kawasan perdesaan namun masih sesuai dengan ciri dasar pembagian kerja di perdesaan yang berbasis ekonomi pertanian; (b) apakah nilai kesetaran kehidupan masyarakat perdesaan dengan kehidupan masyarakat perkotaan mempunyai nilai yang sama, mengingat masing-masing mempunyai ciri yang berbeda.

Secara umum nilai kesetaraan dapat dilihat dari tingkat kesejahteraan masyarakat, yang diukur dari kesetaran mendapatkan lapangan kerja, dan pendapatan. Nilai pendapatan itu harus dapat dinikmati untuk dapat memberikan daya atau kemampuan mencukupi baik kebutuhan primer seperti kebutuhan pangan, papan, pendidikan dan kesehatan, maupun kebutuhan sekunder untuk kenyamanan hidup dan kualitas kehidupan yang setara antara masyarakat perdesaan dan perkotaan.

\section{Issue Kebijaksanaan Pengembangan Masyarakat Perdesaan}

Pada umumnya masalah-masalah yang dihadapi dalam pembangunan perdesaan berkisar pada masalah kemiskinan, kualitas hidup, kurangnya prasarana dan sarana pembangunan, dan sebagainya yang saling berkaitan dan merupakan masalah yang kompleks. Dengan demikian usaha untuk mengatasi masalah tersebut diarahkan untuk menanggulangi masalah-masalah tersebut. Berikut ini dikemukakan beberapa konsep dan pendekatan pembangunan perdesaan yang perinah dilaksanakan sebagai berikut:

1. Pengembangan masyarakat (Community Development)

Pengembangan masyarakat didefinisikan sebagai proses, metoda, program, kelembagaan dan gerakan. Usaha yang dilakukan 
mencakup: (a) partisipasi masyarakat sebagai basis menanggulangi masalah yang dihadapi; (b) mendidik dan melatih masyarakat dalam proses demokrasi untuk mengatasi masalah secara bersama; (c) mengaktifkan kelembagaan atau menyediakan fasilitas untuk alih teknoiogi.

Konsep dan pendekatan ini mulai bergeser ketika dimulainya revclusi hijau pada awal tahun 1960 an dan menjelang tahur 1970an, berubah dengan konsep dan pendekatan "Integrated Rural Development".

2. Pembukaan daerah baru dan mendorong migrasi penduduk serta pengelompokan permukiman kecil.

Di beberapa negara yang penyebaran penduduknya tidak merata dan tersedia sumberdaya alam yang belum dimanfaatkan, program ini merupakan program utama.

3. Pemtangunan pertanian

Bagi negara-negara yang sedang berkembang, yang sumberdaya lahannya terbiłtas untuk pembukaan permukiman, pertanian, atau sering mengalami kekurangan pangan, memilih strategi pembangunan pertanain yang padat modal untuk meningkatkan produksi dan pendapatan masyarakat perdesaan. Walaupun strategi ini telah berhasil meningkatkan produksi dan produktivitas perdesaan, tetapi timbul masalah lain seperti adanya polarisasi faktor produksi. Revolusi hijaupun tampaknya tidak berhasil mengurangi urbanisasi serta segala dampaknya di perkotaan, tidak dapat menjangkau petani kecil dan buruh tani, dan adanya wilayah-wilayah yang tetap tidak dapat berkembang karena tidak memiliki sarana irigasi.

Pemikiran selanjutnya berkembang strategi (a) diversivikasi ekonomi perdesaan; (b) redistribusi lahan dan sumberdaya lainnya secara adil dan merata; (c) menyelenggarakan fasilitas penunjang bagi peserta program landreform dan (d) penyediaan fasilitas pelayanan sosial di kota-kota kecil dan permukiman penduduk perdesaan.

4. Industri perdesaan

Beberapa negara termasuk Indonesia mengembangkan program idustri perdesaan melalui promosi industri rumah tangga dan industri kecil serta desentralisasi pengembangan industri. Tampaknya pelaksanaan program inipun tidak berkembang seperti yang diharapkan. Di beberapa daerah terjadi pertumbuhan kota metropolitan dan kota-kuta menengah lainnya menyerap semua kegiatan ini, di 
samping ketidakmampuan sektor industri kecil untuk bersaing dan mengorganisasi diri.

Akibat tidak adanya kaitan yang jelas dan nyata diantara industri kecil dan industri besar, maka manfaat bagi kedua belah pihak kecil sekali. Mereka lebih tampak bersaing dalam hal produksi, teknologi, pemasaran dan sebagainya.

5. Kebutuhan dasar manusia

Konsep dasarnya adalah: (a) secara mendasar pembangunan harus diarahkan untuk mengatasi kemiskinan; (b) perencanaan konsumsi harus diutamakan, sehingga produksi diarahkan untuk pemenuhan kebutuhan dasar; (c) masalah produksi dan distribusi harus diselenggarakan bersama-sama; (d) kesempaian kerja merupakan hal pokok yang harus diciptakan.

Banyak negara berkembang tertarik pada kebijaksanaan pembangunan ini, yaitu dalam hal penyelenggaraan pendidikan dasar, pengadaan fasilita kesehatan, penyediaan air bersih, jaları-jalan perdesaan, pengadaan dan pemugaran rumah-rumah di perdesaan, listrik perdesaan, dan sebagainya. Dalam banyak hal strategi ini telah memberi dampak perbaikan kualitas hidup masyarakat perdesaan, tetapi belum dapat menanggulangi masalah kemiskinan secara mendasar dan luas.

6. Pembangunan desa terpadu (PDT)

PDT merupakan pendekatan yang komprehensif, strategi ini bertujuan untuk meningkatkan produksi, kualitas hidup dan meningkatkan swadaya masyarakat serta pembangunan secara mandiri.

Unsur-unsur pokok dalam program ini adalah: (a) pembangunan pertanian yang padat tenaga kerja; (b) menciptakan kesempatan kerja melalui pekerjaan umum skala kecil; (c) pengembangan industri kecil yang padat karya; (d) swadaya masyarakat secara lokal dan peran serta masyarakat dalam pengambilan keputusan; (e) pengembangan hierarkhi perkotaan yang menunjang pembangunan perdesaan; ( $f$ ) pengembangan tatanan kelembagaan yang memadai untuk koordinasi proyek multi sektor dan lintas sektor.

7. Pusat pertumbuhan dan wilayah pengembangan

Unsur pokok dalam konsep dan strategi PDT adalah tatá ruang atau wilayah. Berdasarkan struktur dan organisasi tata ruang wilayah, maka terdapat suatu pusat dan wilayah pengaruhnya yang saling bergantung secara fungsional. Pusat-pusat tersebut tersusun dalam 
sutu hierarkhi, dan berdasarkan besaran skala, fungsi dan wilayah pengaruhnya, maka hubungan antar wilayah berlangsung melalui jalur hubungan antar pusat-pusat tersebut. Bagi pembangunan wilayah perdesaan, peranan pusat-pusat kecil tersebut selain berfungsi sebagai pasar, pusat pelayanan dan permukiman penduduk, juga dapat dilihat sebagai unsur strategis bagi pelaksanaan pembangunan perdesaan. Di Indonesia keberadaan ibukota kesamatan dan kota kecil lainnya dalam kaitan dengan pembangunar. perdesaan perlu mendapat perhatian.

8. Pendekatan agropolitan

9. Program pemekaran desa, pengelompokkan desa, pemukiman kembali penduduk, dan pembukaan isolasi.

Semua pihak se,jendapat bahwa pembangunan msyarakat perdesaan harus terus ditingkatkan dengan sasaran makin berkurangnya tingkat kesenjangan sosial ekonomi antara masyarakat perdesaan dan perkotaan. Secara khusus pemerintahpun telah melaksanakan berbagai kebijaksanaan dan program yang bertujuan untuk meningkatkan kapasitas produksi dan produktivitas masyarakat perdesaan. Namun berbagai upaya tersebut t:dak akan optimal bila penyelesaian masalah yang bersumber dar faktor internal masyarakat perdesaan dan juga faktor eksternal yang berpengaruh terhadap proses pengembangan ekonomi tidak dilakukan dengan pendekatan holistik. Oleh karena itu pemikiran pendekatan masalah diarahkan melalui pendekatan internal, yaitu pengembangan kemampuan masyarakat perdesaan, dan pendekatan eksternal yaitu penguatan keterkaitan ekonomi antara perdesaan dan perkotaan.

Pendekatan pembangunan seperti itu merupakan bagian dari konsep pembangunan sosial ekonomi yang didasarkan pada jalan pemikiran bahwa peningkatan kemampuan masyarakat merupakan energi sosial yang perlu dibangun di dalam diri masyarakat. Sedangkan penguatan keterkaitan ekonomi perdesaan dan perkotaan merupakan energi ekonomi yang dapat meningkatkan permintaan dan transaksi barang dan jasa yang diproduksi oleh masyarakat perdesaan.

Keduanya merupakan bagian dari upaya pemberdayaan masyarakat yang saling mendukung untuk mempercepat proses perubahan struktural masyarakat perdesaan untuk mewujudkan kesejahteraannya. Model kebijaksanaan tersebut menganut pada prinsip penggabungan pendekatan pertumbuhan dan pemerataan (Mahbub ul Haq, 1995). Pemerataan tidak datang dengan sendirinya, proses pemerataan sering tidak memenuhi harapan masyarakat yang kemampuannya lemah. Ketidakmerataan kemampuar selalu ada, sehingga diperlukan pendekatan sosial yang 
memungkinkan agar proses pembagian dapat berlangsung sejalan dengan perkembangan ekonomi ada melalui proses pengembangan sosial masyarakat.

Model kebijaksanaan tersebut dilandasi pula oleh berbagai perkembangan baru tentang konsep pembangunan yang bertumpu pada masyarakat. Pembangunan adalah untuk mengembangkan kehidupan masyarakat dan harus dapat dilakukan dari, oleh dan untuk masyarakat. Namun demikian bantuan dari luar tetap diperlukan untuk mengatasi masalah kemampuan masyarakat yang berbeda-beda. Dalam masyarakat dengan kehidupan ekonomi yang makin terbuka dengan dunia luar dan kegiatan ekonomi berorientasi pada pasar, peluang-peluang yang ada belum tentu dapat dimanfaatkan oleh masyarakat dengan kemampuan lemah. Dalam hal ini diperlukan pemihakan untuk meningkatkan kemampuan masyarakat untuk pemanfaatan kesempatan dan merespon bantuan yang diberikan sebagai energi sosial dalam rangka mengadakan perubahan struktur ekonominya.

\section{Peningkatan Kemampuan Masyarakat Perdesaan}

Berbagai kondisi yang tampak pada masyarakat perdesaan adalah rendahnya kualitas kehidupan sebagian besar masyarakat perdesaan bila dibanding dengan masyarakat perkotaan. Hal ini ditunjukkan dengan besarnya jumlah penduduk miskin di desa yang lebih tinggi daripada uaerah perkotaan. Hal tersebut disebabkan oleh tingkat pengangguran di desa meningkat, sementara itu di kota menurun. Distribusi pendapatan penduduk perdesaan walaupun makin merata dibanding di perkotaan, namun nilai nominalnya kecil.

Tingkat pengangguran yang tinggi disebabkan oleh tidak berkembangnya kesempatan kerja di daerah perdesaan, bahkan sebagian masyarakat tidak memperoleh asset produksi. Masalah ini akan semakin bertambah bila pertumbuhan sektor pertanian lambat, sedang ang'katan kerja terus bertambah.

Disamping itu sistem produksi dan diversifikasi yang dapat meningkatkan pendapatan tidak berkembang. Rendahnya pendapatan juga disebabkan oleh upah yang rendah, produktivitas yang rendah, efisiensi yang rendah. Oleh karena itu surplus hasil usaha masyarakat desa kecil, akumulasi modal tidak terjadi, ditambah lagi dengan rendahnya nilai tukar dibanding dengan produk daerah perkotaan. Akibatnya kesenjangan pendapatan antara penduduk pedesaan dan perkotaan menjadi semakin besar. 
Permasalahan untuk mengurangi kesenjangan pendapatan erat kaitannya dengan rendahnya kapasitas produksi dan produktivitas antara lain disebabkan oleh:

1. Sumberdaya manusia yang masih lemah dari segi kemampuan alih teknologi dan managerial.

2. Akses sarana modal dan prasarana yang dapat disalurkan terbatas.

3. Adopsi teknologi masyarakat berjalan lambat sehingga produktivitas rendah, diversifikasi usaha tidak berkembang, pertambahan nilai teroatas. Akibatnya pendapatan dan surplus yang dinikmati masyarakat perdesaan tetap kecil.

Lingkaran setan ini perlu dipecahkan dengan bantuan pihak luar, yaitu pemerintah, masyarakat yang mampu serta berbagai pihak yang dapat melakukan kerjasama untuk membantu meningkatkan kemampuan masyarakat yang posisinya lemah. Proses pemberdayaan masyarakat mengandung tiga tindakan utama di dalamnya yaitu:

1. Menciptakan iklim yang memungkinkan potensi pihak yang kuat dari luar dapat dimanfaatkan masyarakat.

2. Memperkuat potensi dari dalam yang dimiliki masyarakat untuk dapat dimanfaatkan pihak yang kuat.

3. Melindungi dan mencegah terjadinya persaingan yang tidak seimbang serta mencegah eksploitasi yang kuat atas yang lemah. (Ginanjar Kartasasmitā, 1997).

Masyarakat dengan produktivitas tinggi lebih cepat berkembang dan yang lemah akan tertinggal. Untuk itu maka pemerintah dituntut meningkatkan pemeratan kesempatan disamping upaya pemberdayaan.

Jadi proses peningkatan kemampuan masyarakat dapz.t lebih optimal bila dilakukan upaya pemeratan kesempatan sehingga peningketan pendapatan dan kualitas hidup masyarakat perdesaan dapat maksimal. Dalam konteks keruangan pemeratan kesempata. 1 bagi masyarakat perdesaan itu ditransformasikan ke dalam bentuk per guatan keterkait.an desa-kota. Keterkaitan ekonomi desa-kota merupakar upaya penting untuk memperbesar pemanfaatan kemampuan dan kese npatan yang terbuka bagi masyarakat dalam pengembangan ekonomi perdesaan dengan melihat potensi pertumbuhan di daerah perkotaan.

\section{Pembangunan Perdesaan dengan Pendekatan Keterkaitan Desa dan Kota}

Secara geografis, pendekatan ini didasarkan pada teori pembangunan Pusat-Pinggiran (Core-Periphery). Konsep ini memandang daerah pusat (kota) dan tepi (desa) sebagai suatu sistem keruangan. 
Paradigma Friedman membahas adanya suatu sistem keruangan yang lengkap yang melihat daerah pusat dan tepi, wilayah pusat diartikan sebagai teritorial tertentu dengan subsistem masyarakat teratur yang memiliki kapasitas tinggi memacu pembaruan dan menyerap perubahan inovatif.

Daerah tepi merupakan subsistem yang jalur perkembangannya dipengaruhi oleh lembaga yang ada di pusat, sehingga daerah ini mempunyai ketergantungan susbtansial. Dengan kondisi tersebut dapat dilihat bahwa ada jalinan yang berupa interaksi antara wilayah fusat dan daerah tepi (Raldi H. Koestoer, 2001).

Menurut G. Myrdal, "core regions" adalah sebagai magnit yang dapat memperkuat pertumbuhan ekonomi dengan sendirinya, karena adanya sebab-sebab kumulatif ke arah perkembangan (cumulative upward causation); seperti arus buruh dari $\mathrm{P}$ ke $\mathrm{C}$, tenaga terampil, modal dan barang perdagangan yang secara spontan berkembang di dalam ekonomi pasar bebas untuk menunjang pertumbuhan di lokasi tertentu atau wilayah tertentu. Dengan demikian akan terjadi pertumbuhan yang makin lama makin pesat (polarization of growth). "Polarization of growth" ini dapat menimbulkan "backwash effects" atau akibat-akibat yang dapat menghambat pertumbuhan wilayah lain darimana tenaga terampil, modal dan barang perdagangan ditarik ke situ. Daerah yang terkena "backwash effects ini yang disebut daerah "periphery". Apabila "spreads effects" dari C ke P lebih kuat, maka "backwash effects" dapat diatasi. Oleh karena itu untuk memperbesar "spread effects" Myrdal mengemukakan perlu adanya campur tangan dari pemerintah, misalnya dengan pengendalian migrasi, pembangunan "periphery", program pembangunan perdesaan (Myrdal dalam J. Hinderink, 1988). Senada dengan Myrdal, A. Hirshchman mengemukakan, bahwa penanaman modal di "core regions" akan mempercepat pertumbuhan di $\mathrm{C}$, dan efek polarisasi pembangunan akan digantikan oleh "trickling down effects" pembangunan. "Trickling down" ini disebabkan oleh perubahan kumulatif di daerah pusat (core regions). Jadi trickling down effects sama dengan spread effects. Hirschman juga s̊pendapat dengan Myrdal, bahwa dalam hubungan antara C dan P dialam arti polarisasi ekonomi perlu adanya campur tangan pemerintah dalam pembangunan. Campur tangan pemerintah ini berupa kebijaksanaan pembangunan yang mengacu pada pendekatan pemerataan kesempatan dan keterkaitan desa kota.

Proses pemerataan akses kesempatan bagi masyarakat perdesaan merupakan bagian dari upaya untuk memperkuat kemampuan mayarakat 
melibatkan diri dalam proses kegiatan dan memanfaatkan hasil pembangunan (Mahbub ul Haq, 1995). Pendekatan ini merupakan strategi pengembangan masyarakat perdesaan, agar kesenjangan makin berkurang antara masyarakat desa dengan kota.

Namun demikian proses keterkaitan ekonomi desa kota tidak dapat berjalan dengan optimal jika tidak dijalankan upaya langsung yang menjangkau kelompok sasaran masyarakat berupa akses kesempatan berproduksi secara efektif dan menguntungkan. Sehubungan dengan strategi untuk meningkatkan pemerataan akses kesempatan dapat dilakukan melalui:

1. Pemerataan akses ke penguasaan aset produksi lahan, kapital dan teknologi.

2. Pemerataan akses ke pelayanan kesehatan dan pendidikan.

3. Pemerataan akses pemasaran dan informasi kegiatan usaha produktif.

4. Pemerataan akses ke bantuan teknis dan kerjasama kemitraan dengan usaha ekonomi kuat.

$\mathrm{Di}$ Indoriesia pembangunan perdesaan dengan pendekatan keterkaitan desa kota telah dilaksanakan studi PARUL (Poverty Allevation Through Rural Urban Linkages):

1. Melakukan kajian beberapa keterkaitan desa kota di dalam keछiatan ekonomi lokal dan kebutuhan intervensi pemerintah untuk memperkuat pengelolaan di tiga propinsi (Sulut, Sulsel, Irian Jaya-Sorong).

2. Membentuk konsensus dalam perencanaan dan pengelolaan keterkaitan desa kota dilihat dari aspek mata rantai produksi di tingkat kabupaten.

3. Mengevaluasi program yang ada untuk mendukung pelaksanaan pengelolaan keterkaitan desa kota.

Pendekatan pengelolaan selalu bertumpu pada inisiatif dan partisipasi masyarakat, lembaga swadaya masyarakat, swasta serta aparat birokrasi lokál. Namun demikian pengembangan ekonomi ini perlu mempertimbangkan pengembangan komoditas, mata rantai keterkaitan industrl lokal dan global (perdagangan, tenaga kerja, kapltal, transportasl, kawasan desa kota), kemitraan ekonomi lemah dan ekonomi kuat, serta keterpaduan program serta kegiatan yang dilaksanakan para pihak yang berkepentingan.

Dengan program mengaitkan kegiatan desa kota, diharapkan hasilnya adalah sebagai berikut:

1. Terciplanya produksi komoditas kompetitif. 
2. Terciptanya lapangan kerja yang produktif, masyarakat yang berpendidikan tinggi, berjiwa kewiraswastaan.

3. Tersedianya sarana dan prasarana ekonomi produktif.

4. Tersedianya akumulasi kapital untuk produksi.

5. Terbentuknya jaringan kerja produksi, pengolahan produk, pemasaran dan perdagangan.

6. Kuatnya kapasitas kelembagaan masyarakat dan pemerintah dalam pengelolaan pengembangan ekonomi lokal.

Sehubungan dengan pola pelaksanaannya, terdapat beberapa pemikiran yang dapat dikembangkan sebagai dasar pelaksanaan, yaitu dengan deliniasi wilayah. Deliniasi wilayah dapat dilakukan berdasarkan konsep perwilayahan, yaitu konsep homogenitas, nodalitas dan unit program. Berdasarkan konsep ini untuk mengefektifkan pemerataan kesempatan, maka sasaran pengembangan dapat dikategorikan menjadi empat kelompok sasaran:

1. Tipe 1, kelompok sasaran masyarakat yang tinggal di desa-desa dengan kegiatan subsisten dan terisolasi.

2. Tipe 2, masyarakat dengan potensi ekonomi dan keterkaitan desa kota lemah.

3. Tipe 3, masyarakat desa yang potensi sudah berkembang, belum terjadi diversifikasi, dan keterkaitan sudah berkembang

4. Tipe 4, desa yang sudah berkembang dan sudah terjadi diversifikasi ekonomi, keterkaitan desa kota kuat.

Bagi desa tipe 1, input program yang dapat diberikan untuk memenuhi kebutuhan dasar, dalam bentuk bantuan materi langsung dan bantuan program sosial secara kelompok, serta mengikutsertakan mereka dalam usaha penanganan khusus.

Bagi desa tipe 2 dan 3, input program yang diberikan berupa upaya peningkatan pendapatan melalui peningkatan kemampuan produksi, bantuan teknis terpadu. Untuk meningkatkan keterkaitan desa kota dan meningkatkan akses pemasaran disediakan prasarana transportasi.

Bagi desa tipe 4, input program yang diberikan untuk meningkatkan basis intensifikasi dan diversifikasi kegiatan agribisnis, di samping bantuan teknis yang diberikan seperti kepada tipe 2 dan 3. dalam konteks pembangunan wilayah, untuk memfasilitasi proses produksi dan pemasaran perlu dikembangkan lokasi pusat industri pengolahan dan jasa pada lokasi potensial yang berfungsi sebagai sentra pengembangan, yang dapat memperkuat keterkaitan desa kota. 


\section{Tantangan pelaksanaan}

Tantangan pelaksanaan proses pembangunan masyarakat perdesaan dengan keterkaitan desa kota adalah bagaimana menyiapkan masyarakat untuk terlibat memanfaatkan bantuan dan proses pelaksanaan program yang disediakan pemerintah. Disamping itu dalam hal pemenuhan prasarana, perlu keseimbangan dan keterpaduan dana pemerintah yang dialokasikan untuk memenuhi kebutuhan antara desa dan kota.

\section{Kesimpulan}

Dalam rangka pengembangan masyarakat perdesaan, baik melalui pendekatan peningkatan kemampuan masyarakat dan keterkaitan desa kota, beberapa hal yang perlu diperhatikan adalah bahwa suksesnya pelaksanaan pendekatan ini tergantung pada keterlibatan berbagai pihak di tingkat pemerintah, swasta, lembaga masyarakat dan kelompok masyarakat sasaran sendiri. Pengembangan kelembagaan yang efektif sangat diperlukan, baik di tingkat pemerintah dan di masyarakat, dana tersedia dan mudah diakses, penyiapan masyarakat dan petunjuk teknis harus efektif. Proses peningkatan kemampuan masyarakat dan penguatan keterkaitan desa kota memerlukan proses desentralisasi dan otonomi kepada daerah dan partisipasi masyarakat.

\section{Daftar Pustaka}

Evans, H, Ermy. 1994. Rural Urban Linkages: Operational Implications for Self Sustained Development. Pratical Research For Planning. Inc.

Hinderink, J. 1988. Regional and Rural Development Planning Serles. Indonesia: Faculty of Geography, Gadjah Mada University, Yogya'rarta.

Kakazu, Hiroshi. 1994. Sustainable Development of Small Island Economic. San Fransisco: Westview Press.

Kartasasmita, Ginanjar. 1997. Konsep dan Model Perencanaan Pembangunan di Indonesia dalam Sugijanto Sugijoko "Perencanaan Pembangunan di Indonesia". Indonesia: Penerbit PT Gramedia.

Koestoer H, Raldi, dkk. 2001. Dimensi Keruangan Kota: Teori dan Kasus. Indonesia: UI Press. 
I| Keterkaitan Desa-Kota: Sebagai Alternatif Pembangunan Perdesaan

Nas, P.J.M. 1979. Kota di Dunia Ketiga. Jakarta: Bhratara Karya aksara.

UI Haq, Mahbub. 1995. Tirai Kemiskinan: Tantangan Untuk Dunia Ke Tiga. Edisi Kedua. Jakarta: Penerbit Yayasan Obor. 